\title{
PERAN ORANGTUA DALAM PENCEGAHAN DAN PENANGANAN PENYALAHGUNAAN NARKOBA PADA REMAJ A
}

\author{
Shafila Mardiana Bunsaman ${ }^{1}$, Hetty Krisnani² \\ 1,2Program Studi Kesejahteraan Sosial, Fakultas IImu Sosial dan IImu Politik, \\ Universitas Padjadjaran \\ 1Shafila17001@mail.upad.ac.id, ${ }^{2}$ hettykrinani@yahoo.com
}

\begin{abstract}
ABSTRAK
Masa remaja merupakan masa peralihan antara masa kanak-kanak dan masa dewasa. Masa ini merupakan masa yang paling krusial, dimana pada masa ini individu berjuang untuk menemukan jati dirinya. Pada tahap pencarian jati diri membuat remaja ingin mencoba hal-hal yang baru dan mencari jati diri dengan bergaul dengan kelompok sebayanya. Kelompok sebaya memiliki pengaruh yang cukup kuat pada seseorang terutama remaja. Oleh karena itu jika seorang remaja memiliki mental dan kepribadian yang cukup lemah serta berada di lingkungan yang tidak sehat, tidak dapat dipungkiri bahwa ia akan terjerumus ke dalam hal-hal negatif, termasuk penyalahgunaan narkoba. Maraknya kasus penyelahgunaan narkoba di kalangan remaja merupakan masalah yang memprihatinkan juga mengkhawatirkan, terutama bagi para orang tua. Hingga saat ini upaya pencegahan penyalahgunaan narkoba yang paling efektif adalah upaya pencegahan yang dilakukan oleh keluarga terutama orang tua. Karena orangtua dan keluarga merupakan lingkungan yang paling dekat yang dapat mempengaruhi perilaku seseorang. Oleh karena itu penting untuk menguatkan peran orangtua dalam mengantisipasi bahaya narkoba.
\end{abstract}

Kata kunci: Remaja, Peran Orangtua, Penyalahgunaan Narkoba

\section{ABSTRAK}

Adolescence is a transition between childhood and adulthood. This is the most crucial period, which individuals struggle to find their true indentity. At the stage of searching for identity, adolecents want to try new things and seek identity by hanging out with their peers. Peer groups have a strong enough influence on an individual, especially adolecent. Therefore, if an adolesent has a weak mental and personality, it cannot be denied that s/he will fall into negative things, including drug abuse. The cases of drug abuse among adolecents keep increasing and it's really worrying, especially for parents. Until now the most effective drug abuse prevention efforts are prevention efforts undertaken by families, especially parents. Because parents and family are the closest environment that can influence someone's behavior. Therefore, it is important to strengthen the role of parents in anticipating the dangers of drugs.

Keywords: Adolecent, Role of Parents, Drug Abuse

\section{PENDAHULUAN}

Penyalahgunaan narkoba telah merambah ke seluruh elemen masyarakat, tidak terkecuali dengan para remaja. Setiap tahunnya kasus penyalahgunaan narkoba oleh remaja di Indonesia terus menerus meningkat. Kasusnya sama seperti fenomena gunung es, dimana yang tampak hanya bagian atasnya saja sedangkan bagian terbesar di bawahnya tidak tampak. Menurut World Health Organization (WHO), jika ada satu kasus yang terdata, maka ada sepuluh kasus disekitarnya yang tidak terdeteksi (Anonim, 2007:48-49). Menurut survei yang dilakukan oleh Badan Narkotika
Nasional (BNN) dan Lembaga IImu Pengetahuan Indonesia (LIPI), pada tahun 2018 angka penyalahgunaan narkoba di kalangan pelajar (dari 13 ibukota provinsi di Indonesia) mencapai angka 2,29 juta orang. Angka tersebut setara dengan 3,2 persen dari populasi kelompok tersebut.

Sampai saat ini penyebaran narkoba sudah hampir tidak dapat dicegah. Mengingat betapa mudahnya orang-orang mendapatkan narkoba dari oknumoknum yang tidak bertanggung jawab. Tentu saja hal ini sangat mengkhawatirkan bagi para orangtua, organisasi masyarakat, dan pemerintah. 


\begin{tabular}{|c|c|c|c|c|}
\hline $\begin{array}{c}\text { Prosiding Penelitian \& } \\
\begin{array}{c}\text { Pengabdian Kepada } \\
\text { Masyarakat }\end{array}\end{array}$ & $\begin{array}{c}\text { e ISSN : 2581-1126 } \\
\text { p ISSN : 2442-448X }\end{array}$ & Vol 7, No: 1 & Hal: 221 - 228 & April 2020 \\
\hline
\end{tabular}

Penyalahgunaan narkoba oleh remaja merupakan masalah yang cukup serius, karena narkoba dapat merusak masa depan para remaja. Generasi muda merupakan sasaran yang strategis bagi para pengedar narkoba. Oleh karena itu, generasi muda sangat rawan terjerumus penyalahgunaan narkoba (Lydia Herlina Martono dan Satya Joewana, 2008: 26). Penanganan serius perlu dilakukan terutama oleh para orangtua. Peran orangtua sangat dibutuhkan dalam rangka pencegahan dan penanggulangan penyalahgunaan narkoba. Orangtua dan keluarga merupakan lingkungan yang paling dekat yang dapat mempengaruhi perilaku anak. Anak memandang orangtua sebagai figur mereka dan pada akhirnya mereka akan meniru perilaku orangtuanya. Kepala Bagian Pengawasan dan Pengendalian Direktorat Reserse Narkoba Polda Metro J aya Ajun Komisaris Besar Sri Hastuti menyatakan bahwa kerentanan remaja dipengaruhi oleh faktor lingkungan. Kondisi mental remaja biasanya selalu ingin tahu dan labil, apabila ditambah dengan pergaulan yang tidak sehat, maka dapat menjerumuskan mereka ke praktik penyalahgunaan narkoba. Situasinya akan lebih parah jika keluarga tidak memperhatikan anakanak (Kompas.com, 2013).

Sudah banyak upaya pemberantasan narkoba yang dilakukan, akan tetapi masih sedikit kemungkinan untuk menghindarkan narkoba di kalangan remaja, bahkan anak-anak usia SD dan SMP pun sudah banyak yang terjerumus dalam penyalahgunaan narkoba. Saat ini, upaya yang paling efektif untuk mencegah penyalahgunaan narkoba pada anakanak dan remaja adalah pendidikan keluarga. Para orangtua diharapkan dapat mengawasi dan mendidik anak-anak mereka sehingga selalu menjauhi penyalahgunaan narkoba. Peran orangtua harus diperkuat dalam mengantisipasi bahaya narkoba.

\section{KAJI AN PUSTAKA}

\section{Remaja}

Kata "remaja" berasal dari bahasa latin adolescene yang memiliki arti to grow atau to grow maturity (Golinko, 1984, Rice 1990 dalam Jahja, 2011). Papalia dan Olds memberikan pengertian remaja secara implisit melalui pengertian masa remaja atau adolescene, menurut Papalia dan Olds masa remaja merupakan masa transisi perkembangan antara masa kanak-kanak dan dewasa, pada umumnya masa remaja dimulai sejak usia 12-13 tahun sampai dengan akhir belasan tahun atau awal 20 tahun.sementara World Health Organization (WHO) mendefinisikan remaja ke dalam tiga kriteria yaitu biologik, psikologik, dan sosial ekonomi. Lebih lengkapnya remaja menurut definisi WHO yaitu (1) individu yang berkembang dari ketika pertama kali menunjukan tanda-tanda seksual sekundernya sampai ia mencapai kematangan seksual, (2) individu yang tengah mengalami perkembangan psikologis dan pola identifikasi dari anak-anak menjadi dewasa, dan (3) adanya peralihan dari ketergantungan sosial ekonomi yang penuh kepada keadaan yang lebih mandiri.

Masa remaja sering disebut sebagai masa peralihan atau masa transisi antara masa kanakkanak dan masa dewasa. Pada masa remaja akan terjadi perubahan-perubahan yang penting dalam kehidupan manusia, meliputi perubahan fungsifungsi jasmani dan rohani. Tidak dapat dipungkiri juga bahwa masa remaja merupakan masa yang sangat rentan terhadap pengaruh lingkungan. Masa remaja merupakan salah satu tahap perkembangan yang krusial, hal ini disebabkan karena individu harus mencapai perasaan identitas ego yang teguh. Pada masa ini individu berjuang untuk menemukan jati dirinya, berupa identitas seksual, ideologis, dan pekerjaan (Erikson dalam Feist dan Feist, 2008).

Pada tahap pencarian identitas, membuat remaja selalu mencoba hal-hal baru dan mencari jati diri dengan bergaul dengan teman sebayanya. Menurut ahli Psikologi Perkembangan, remaja kerapkali menolak standar yang telah ditetapkan oleh orangtua dan akan lebih menerima penilaian teman sebayanya. Jika penilaian teman sebaya tidak berbeda jauh dengan standar orangtua atau keluarga maka kemungkinan mereka mengalami krisis identitas menjadi semakin kecil. Akan tetapi, kenyataannya penilaian teman sebaya dan standar keluarga seringkali bertentangan yang dapat menyebabkan konflik. Hal ini lah yang menyebabkan terjadinya krisis identitas dan membuat remaja mencoba dan bereksperimen dalam berbagai hal. Dalam upaya pencarian identitas dirinya, remaja mungkin meninggalkan rumah, mengembara sendirian untuk menemukan identitas dirinya, bereksperimen dengan obat psikotropika dan seks, atau memberontak dan melawan kemapanan masyarakat (Erikson dalam Alwisol, 2008). Oleh karena pergumulan di masa ini, remaja mempunyai kebutuhan sosialisasi yang optimal, dan membutuhkan perhatian serta dukungan dari orangtua dan keluarga dalam kerentanan di masa remaja. Remaja dapat terjebak dalam perkembangan pribadi yang lemah dan bahkan dapat dengan mudah terjerumus ke dalam 


\begin{tabular}{|c|c|c|c|c|}
\hline $\begin{array}{c}\text { Prosiding Penelitian \& } \\
\begin{array}{c}\text { Pengabdian Kepada } \\
\text { Masyarakat }\end{array}\end{array}$ & $\begin{array}{c}\text { e ISSN : 2581-1126 } \\
\text { p ISSN : 2442-448X }\end{array}$ & Vol 7, No: 1 & Hal: $221-228$ & April 2020 \\
\hline
\end{tabular}

penyalahgunaan narkoba jika kebutuhan remaja kurang diperhatikan terutama oleh orangtua dan keluarga.

\section{Narkoba}

Narkoba merupakan singkatan dari Narkotika, Psitropika dan Bahan Adiktif lainnya (Subagyo Partoraharjo, 2004). Narkoba atau narkotika berasal dari bahasa Yunani yakni narke atau narkam yang memiliki arti terbius sehingga tidak dapat merasakan apa pun. Sedangkan dalam bahasa Inggris, narcose atau narcosis memiliki arti menidurkan atau pembiusan. Dalam UndangUndang RI Nomor 35 Tahun 2009 narkoba dijelaskan sebagai zat atau obat yang berasal dari tanaman atau pun bukan tanaman, baik sintesis ataupun semi sintesis yang dapat menyebabkan penerunan atau perubahan kesadaran, hilangnya rasa, mengurangi bahkan sampai menghilangkan rasa nyeri, serta dapat menimbulkan ketergantungan yang dibedakan ke dalam berbagai golongan.

Menurut Undang-Undang Nomor 35 Tahun 2009, narkoba dibagi ke dalam tiga jenis, yaitu narkotika, psitropika, dan zat adiktif lainnya.

1. Narkotika

Narkotika merupakan sejenis obat atau zat yang berasal dari tanaman atau bukan tanaman, baik sintetis ataupun bukan, yang dapat menyebabkan penurunan maupun perubahan kesadaran serta hingnya rasa. Narkotika memiliki daya adiksi yang berat serta memiliki daya toleran dan daya habitual yang sangat tinggi. Hal ini lah yang menjadi penyebab pemakai narkotika sulit terlepas dari cengkramannya. Narkotika terbagi ke dalam tiga golongan, yaitu:

Golongan I: narkotika jenis ini hanya dapat digunakan untuk tujuan pengembangan ilmu pengetahuan dan tidak dapat digunakan dalam terapi serta memiliki potensi ketergantungan yang sangat tinggi. Contohnya ganja, kokain, dan heroin.

Golongan II: dapat digunakan untuk pengobatan, digunakan dalam terapi atau untuk pengembangan ilmu pengetahuan. Serta memiliki potensi ketergantungan yang sangat tinggi. Contohnya petidine dan mrphin.

Golongan III: memiliki khasiat untuk pengeobatan serta banyak digunakan dalam terapi dan dapat digunakan dengan tujuan pengembangan ilmu pengetahuan. Narkotika jenis ini memiliki potensi ketergantungan ringan. Contohnya adalah codein dan turunannya.

2. Psikotropika

Psikotropika merupakan obat atau zat, baik yang sintetis ataupun alamiah, yang memiliki khasiat psikoaktif melalui pengaruh elektif pada susunan saraf pusat serta dapat menyebabkan perubahan khas pada aktivitas mental dan juga perilaku. Menurut UndangUndang Nomor 5 Tahun 1997, psikotopika dibagi ke dalam beberapa golongan diantaranya:

Golongan I: Psikotropika jenis ini hanya dapat digunakan untuk tujuan pengembangan ilmu pengetahuan, tidak dapat digunakan dalam terapi, serta memiliki potensi ketergantungan yang kuat. contohnya adalah LSD, MDMA, dan STP.

Golongan II: memiliki khasiat untuk pengobatan serta dapat dignakan dalam terapi ataupun untuk pengembangan ilmu pngetahuan. Dan memiliki potensi ketergantungan yang kuat. Contohnya adalah rilatin, fensiklidin, metamfetamin, dan amfetamine.

Golongan III: psitropika jenis ini memiliki daya adiksi yang sedang dan dapat digunakan untuk pengobatan serta untuk pengembangan ilmu pengetahuan. Contohnya adalah buprenorsina, lumibal, dan fleenitrazepam.

Golongan IV: psitropika jenis ini memiliki daya adiksi yang ringan serta dapat digunakan untuk pengobatan dan pengembangan ilmu pengetahuan. Contohnya adalah diaxepam dan nitrazepam.

Dalam ilmu famakologi, psikotropika digolongkan kedalam tiga golongan yaitudepresan, stimulan, dan halusinogen (Subagyo Partodiharjo, 2004).

3. Zat Adiktif Lainnya

Zat adiktif lainnya merupakan zat-zat selain narkotika dan psitropika yang dapat menimbulkan ketergantungan baik secara fisik maupun mental. Contohnya alkohol, rokok atau tembakau, thiner dan zat lainnya, seperti aseton, cat, bensin, lem, dan penghapus cair yang apabila dihirup dapat membukan (Alifia, 2008).

\section{Faktor Penyebab Penyalahgunaan Narkoba}

Menurut Libertus Jehani dan Antoro (2006), penyebab seseorang terjerumus dalam 


\begin{tabular}{|c|c|c|c|c|}
\hline $\begin{array}{c}\text { Prosiding Penelitian \& } \\
\begin{array}{c}\text { Pengabdian Kepada } \\
\text { Masyarakat }\end{array}\end{array}$ & $\begin{array}{c}\text { e ISSN : 2581-1126 } \\
\text { p ISSN : 2442-448X }\end{array}$ & Vol 7, No: 1 & Hal: $221-228$ & April 2020 \\
\hline
\end{tabular}

penyalahgunaan narkoba disebabkan oleh faktor internal dan eksternal.

1. Faktor Internal

a. Kepribadian

Seseorang dengan kepribadian yang labil, kurang baik, dan mudah terpengaruh oleh orang lain akan lebih mudah terjerumus ke dalam penyalahgunaan narkoba.

b. Keluarga

J ika seseorang memiliki keluarga dengan hubungan yang kurang harmonis makan akan mengakibatkan orang tersebut menjadi mudah putus asa dan frustasi.

c. Ekonomi

Sulitnya mencari pekerjaan dapat menimbulkan keinginan seseorang untuk bekerja sebagai pengedar narkoba. Akan tetapi seseorang dengan keadaan ekonomi yang cukup pun tetap dapat terjerumus ke dalam penyalahgunaan narkoba ketika mereka kurang mendapatkan perhatian dari keluarga atau masuk ke dalam lingkungan yang salah.

2. Faktor Eksternal

\section{a. Pergaulan}

Teman sebaya memiliki pengaruh yang cukup kuat pada perilaku seseorang terutama remaja yang memiliki mental dan kepribadian yang cukup lemah. Oleh karena itu para remaja dapat dengan mudah terjerumus dalam penyalahgunaan narkoba.

b. Sosial atau Masyarakat

Lingkungan sosial atau lingkungan masyarakat yang tidak baik, cenderung apatis, dan tidak memperdulikan keadaan lingkungan sekitar dapat menjadi penyebab marknya penyalahgunaan narkoba di kalangan remaja.

\section{Dampak Penyalahgunaan Narkoba}

Bila diperinci satu persatu, penyalhgunaan narkoba memiliki dampak yang sangat banyak dan kebanyakan berdampak negatif. Secara umum, dampak penyalahgunaan narkoba dapat terlihat secara fisik, psikis bahkan sosial seseorang

1. Dampak terhadap fisik

Ada banyak dampak penyalahgunaan narkoba terhadap fisik penggunanya, diantaranya adalah gangguang pada sister saraf (neurologis), gangguan jantung dan pembuluh darah (kardiovaskuler), gangguan pada kulit (dermatologis), gangguan pada paru-paru (pulmoner), gangguan kesehatan reproduksi, sakit kepala, mual-mual dan muntah-muntah, peningkatan suhu tubuh, pengecilan hati dan kesulitan tidur. Penggunaan narkoba melalui jarum suntik terutama yang dipakai secara bergiliran dapat menimbulkan risiko penularan penyakit menulr seperti Hepatitis B, C, dan HIV. Penyalahgunaan narkoba pun bisa berakibat fatal apabila terjadi overdosis.

2. Dampak terhadap psikis

Beberapa dampak psikis yang akan dirasakan oleh para pengguna narkoba diantaranya adalah hilangnya kepercayaan diri, sering tegang dan geilisah, penuh curiga, kesulitan berkonsentrasi, penuh curiga, perasaan kesal dan tertekan, merasa tidak aman, dan cenderung menyakiti diri sendiri bahkan sampai bunuh diri.

3. Dampak pada lingkungan sosial

Selain berdampak pada fisik dan psikis seseorang, penyalahgunaan narkoba juga dapat berdampak pada lingkungan sosial seseorang diantaranya adalah anti-sosial dan asusila, dikucilkan oleh lingkungan masyarakat, menjadi beban keluarga dan masa depan menjadi suram.

\section{Peran Orangtua}

Orangtua memiliki peran penting dalam membimbing serta mendampingi anak-anak mereka, baik dalam pendidikan formal ataupun pendidikan non-formal. Peran orangtua dapat memengaruhi perkembangan anak dalam aspek kognitif, efektif, dan psikomotori. Lestari (2012) menyatakan bahwa peran oragtua adalah cara yang digunakan oleh orangtua yang berkaitan dengan pandangan mengenai apa saja yang harus dilakukan dalam mengasuh anak. Sementara menurut Hadi (2016) orangtua memiliki kewajiban dan juga tanggung jawab untuk mengasuh, mendidik, memelihara, dan melindungi anak.

Dalam keluarga, orangtua memiliki peran yang sangat penting dalam perkembangan anak. Lingkungan keluarga merupakan lingkungan paling pertama yang sering dijumpai oleh anak. oleh karena itu lingkungan keluarga akan sangat memengaruhi perilaku anak. Maka dari itu, orangtua harus memberikan bimbingan serta memberi contoh yang baik pada anak.

Dalam sebuah keluarga setiap anggota keluarga memiliki peranannya masing-masing. Menurut Jhonson (2010) peran keluarga adalah sebagai berikut: (1) Seorang ayah berperan sebagai kepala keluarga, pencari nafkah, pendidik, dan pelindung serta pemberi rasa ama; (2) Seorang ibu berperan 


\begin{tabular}{|c|c|c|c|c|}
\hline $\begin{array}{c}\text { Prosiding Penelitian \& } \\
\begin{array}{c}\text { Pengabdian Kepada } \\
\text { Masyarakat }\end{array}\end{array}$ & $\begin{array}{c}\text { e ISSN : 2581-1126 } \\
\text { p ISSN : 2442-448X }\end{array}$ & Vol 7, No: 1 & Hal: $221-228$ & April 2020 \\
\hline
\end{tabular}

sebagai pengurus rumah tangga, pengasuh, pelindung, dan pendidik bagi anak-anaknya; (3) Dan anak-anak akan melaksanakan peranan psikososial sesuai dengan tingkat perkembangan mereka. Tirtarahardja (2005) menyimpulkan bahwa dalam sebuah keluarga orangtua berperan sebagai panutan, pengajar, dan sebagai pemberi contoh. Berdasarkan pengertian tersebut maka dapat disimpulkan bahwa orangtua berperan sebagai pendidik, pelindung, pengaruh, dan pemberi contoh dalam sebuah keluarga.

\section{METODE}

Pada artikel kali ini metode penelitian yang digunakan adalah metode penelitian deskriptif kualitatif. Menurut Nana Syaodih Sukmadinata (2011:73) penelitian deskriptif kualitatif ditujukan untuk mendekripsikan serta menggambarkan fenomena-fenomena yang sudah ada, baik fenomena yang bersifat alamiah maupun fenomena yang bersifat rekayasa manusia. Sedangkan data yang digunakan adalah data sekunder. Data sekunder merupakan data yang diperoleh seara tidak langsung dari sumbernya. Data sekunder diperoleh dari penelitian-penelitian terdahulu dan juga buku referensi.

\section{PEMBAHASAN}

Menurut para ahli Psikologi Perkembangan, sejak lahir anak mendapatkan dasa-dasar langsung dari orangtua. Kunci paling pertama dalam mengarahkan pendidikan dan membentuk mental anak terletak pada orangtuanya. Anak akan tumbuh dan berkembang serta mendapatkan pelajaran dan pengalaman melalui apa yang dipelajari dari orangtuanya, hal ini lah yang nantinya akan mengembangkan kepribadian anak. Kepribadian individu memegang peranan penting dalam keberhasilan individu tersebut.

Untuk dapat mencapai keberhasil tersebut individu harus memiliki kerpibadian yang sehat. Kepribadian yang sehat ini dimulai dari kondisi keluarga yang bahagia dan sehat. Menurut penelitian yang dilakukan oleh Nick Stinnet dan J ohn DeFrain (dalam Hidayat, 2013) ada beberapa syarat yang dibutuhkan untuk suatu keluarga disebut sebagai keluarga yang bahagia dan sehat (happy and healthy family), beberapa kriteria yang paling sedikit harus terpenuhi untuk suatu kelaurga menjadi keluarga bahagia dan sehat diantaranya adalah:

\section{Mempunyai Landasan Agama}

Dalam rumah tangga kehidupan beragama sangat dianjurkan. Hal ini disebabkan hanya dalam agama nilai-nilai yang bersifat abadi terkandung. Hasil penelitian menyatakan bahwa keluarga yang tidak relijius, komitmen agamanya rendah, atau yang sama sekali tidak mempunyai komitmen agama memiliki risiki empat kali tidak bahagia, dan beakhir dengan tidak ada kesetiaan, broken home, perceraian, dan kecanduan narkoba.

2. Selalu Bersama Keluarga

Dalam masyarakat modern, ikatan keluarga sering kali mudah longgar. Ini disebabkan masing-masing anggota keluarga disibukan oleh aktivitasnya, sehingga mereka jarang mempunyai waktu untuk bersama keluarga. Hal tersebut dapat menjadi faktor adanya kesenjangan antar orangtua dan anak. Oleh karena itu, sesibuk apapun anggota keluarga harus tetap meluangkan waktu untuk berkumpul.

3. Mempunyai Pola Komunikasi yang Baik

Komunikasi satu arah dan bersifat instruktif dapat menjadi faktor terjadinya disfungsi/disharmoni keluarga. Maka dari itu dibutuhkan komunikasi yang bersifat dua arah, demokratis, dan emosional (dengan perasaan hangat) antara orangtua dan anak sehingga jika terdpat suatu masalah dapat terselesaikan dengan cepat.

4. Saling Menghargai

Setiap anggota keluarga harus saling menghargai sehingga terjalin hubungan yang baik antar anggota keluarga. Hal tersebut dilakukan melelui ucapan, sikap, dan tindakan yang tertanam dalam anggota keluarga.

5. Terdapat I katan Kekeluargaan

Keluarga merupakan ikatan dinamis yang dapat memungkinkan para anggota keluarga tumbuh dan berkembang. Oleh karena itu, sebagai suatu kelompok, keluarga perlu menjaga integritas antar anggotanya dengan komunikasi, pembagian peran, hubungan emosional dan lain sebaginya.

6. Berpikir Positif Ketika Terdapat Krisis

Apabila terjadi sebuah krisis dan benturanbenturan di dalam keluarga maka usahakan untuk mencari penyelesaian bersama. Prioritaskan keutuhan keluarga. Kurang bijaksana jika anggota keluarga saling mehyalahkan atau merasa menang sendiri. Penyelesaian masalah bersama dilakukan sehingga krisis tersebut tidak berlarut dan berkepanjangan. 


\begin{tabular}{|c|c|c|c|c|}
\hline $\begin{array}{c}\text { Prosiding Penelitian \& } \\
\begin{array}{c}\text { Pengabdian Kepada } \\
\text { Masyarakat }\end{array}\end{array}$ & $\begin{array}{c}\text { e ISSN : 2581-1126 } \\
\text { p ISSN : 2442-448X }\end{array}$ & Vol 7, No: 1 & Hal: $221-228$ & April 2020 \\
\hline
\end{tabular}

Jika kondisi-kondisi di atas tidak terpenuhi maka dapat menyebabkan anak-anak rentan terhadap hal-hal negatif. Peran keluarga terutama orangtua sangat penting dalam pengembangan pribadi anak sehingga anak akan tumbuh menjadi remaja yang matang dan dengan mental yang kuat untuk menghadapi masalah serta godaan yang mungkin akan dihadapi, termasuk godaan akan penyalahgunaan narkoba.

Orangtua memiliki peranan yang sangat penting dalam upaya pencegahan penyalahgunaan narkoba. Adapun indikator peran orangtua dalam upaya pencegahan penyalahgunaan narkoba, diantaranya adalah:

\section{Komunikasi Efektif}

Diperlukan komunikasi yang efektif antara orangtua dan anak. Orangtua harus mendegarkan secara aktif serta menunjukan kasih sayang dan perhatian terhadap anak. Ketika anak mencurahkan isi hatinya orangtua harus menghindari sikap menghakimi, merasa benar sendiri, terlalu banyak memberi nasihat seolah-olah mengetahui semua jawaban, menganggap enteng persoalan yang dihadapi oleh anak, serta menghindari penggunaan kata-kata negatif.

2. Mengembangkan Nilai Positif Pada Anak Mengbangkan nilai positif pada anak dengan cara mengajarkan anak membedakan mana yang baik dan yamh buruk, yang benar dan yang salah sejak dini. Hal tersebut memungkinkan anak berani untuk mengambil keputusan atas dorongan hati nuraninya, bukan karena bujukan atau tekanan teman.

3. Membangun Kenyaman dalam Keluarga

Permasalahan dalam keluarga dapat menjadi faktor utama anak terjerumus dalam penyalahgunaan narkoba. Konflik yang berlarut-larut akan menyebabkan anak merasakan suasana ketegangan dengan orangtua. Oleh karena itu perlu menciptakan suasana yang damai dalam keluarga sehingga anak akan merasa lebih terarah dan merasa nyaman.

4. Menjadikan Orangtua Sebagai Teladan dalam Keluarga.

Orangtua wajib membuat dasar perkembangan kepribadian yang kokoh bagi anak, dengan cara menunjukan keteladanan, memiliki norma yang jelas mengenai baik dan buruk serta benar dan salah, tidak banyak menuntut anak, dan membimbing anak dengan kasih sayang serta kepedulian.
5. Mendukung Kegiatan Anak yang Sehat dan Kreatif

Orangtua mendukung kegiatan anak di sekolah, mendukung anak menyalurkan hobi dan keterampilan lainnya sesuai dengan keinginan anak dan tidak menuntut prestasi secara berlebihan.

6. Pendidikan Terhadap Bahaya Narkoba

Orangtua memberikan anak informasi mengenai bahaya narkoba. Selain itu juga orangtua juga membantu mengembangkan anak untuk menolak menggunakan narkoba, jika ada teman yang membujuk atau memaksa ia berhak untuk menolaknya. Selain itu orangtua juga memberikan bimbingan kepada anak untuk mencari kawan sejati yang tidak menjerumuskannya.

Jika sudah terlanjur terjerumus ke dalam penyalahgunaan narkoba, maka setiap orangtua memiliki caranya masing-masing dalam menangani anak mereka. Ada orangtua yang mentolerir, menentang, bahkan menolak. Akan tetapi untuk memudahkan proses pengobatan orangtua perlu mencari informasi sebanyak-banyaknya mengenai narkoba, menerima kondisi anak, dan melakukan penanganan yang baik dan benar dengan melibatkan tenaga ahli. Dalam Undang-Undang Nomor 35 pasal 55 tahun 2009 tertulis bahwa orangtua atau wali pecandu narkoba yang belum cukup umur wajib melaporkan kepada Puskesmas, Rumah Sakit, lembaga rehabilitasi medis dan sosial yang ditunjuk oleh pemerintah untuk mendapatkan pengobatan dan perawatan melalui medis dan sosial (Kohukum, 2009).

Selain peran orangtua, dalam upaya pencegahan dan penanganan penyalahgunaan narkoba di kalangan remaja dibutuhkan pula peran tenaga profesional, salah satunya adalah pekerja sosial. Adapun peran

1. Educator (Pendidik)

Menurut Zastrow (dalam Isbandi Rukminto Adi), pekerja sosial sebagai pendidik diharapkan memiliiki keterampilan sebagai pembicara dan pendidik. Pekerja sosial harus memiliki kemampuan untuk berbicara di depan publik untuk menyampaikan informasi mengenai hal-hal tertentu, sesuai dengan bidang yang ditanganinya. Dalam hal ini pekerja sosial dapat memberikan informasi dan juga pemahaman kepada masyarakat terutama pada orangtua mengenai bahaya narkoba serta pentingnya penanganan penyalahgunaan narkoba oleh remaja yang dapat menimbulkan permasalahan sosial 
lainnya. Pekerja sosial juga dapat memberikan informasi mengenai sistem sumber yang dapat dimanfaatkan untuk mengatasi permasalahan penyalahgunaan narkoba.

2. Broker (penghubung)

Menurut Zastrow (dalam Isbandi Rukminto Adi), pekerja sosial sebagai broker berperan sebagai penghubung antara individu atau kelompok masyarakat yang membutuhkan bantuan maupun layanan masyarakat, akan tetapi mereka tidak tahu di mana dan bagaimana untuk mendapatkan bantuan atau layanan tersebut. Pekerja sosial menjadi penghubung masyarakat terutama keluarga dengan sumber-sumber formal, informl ataupun kemasyarakatan yang dapat dimanfaatkan dalam menangani permasalahan penyalahgunaan narkoba.

3. Fasilitator

Jim Ife (2006) berpendapat bahwa seorang fasiltator bertujuan untuk memberikan dorangan semangat atau membangkitkan semangat klien atau kelompok sasaran sehingga mereka dapat menciptakan perubahan kondisi lingkungannya. Sebagai seorang fasilitator pekerja sosial memiliki peran untuk memotivasi dan membina klien penyalahgunaan narkoba melalui program pelayanan dan memfasilitasi segala sesuatu yang dibutuhkan oleh klien sehingga proses pemulihan agar lebih cepat tercapai dan terlaksana. Pelayanan yang diberikan mencakup pelayan fisik, spiritual, dan sosial.

4. Advokator (pembela)

Menurut Jim Ife (2006) dalam peranan ini pekerja sosial berarti mewakili kepentingankepentingan klien berupa pendapat, lobbying dengan para pemegang kekuasaan, membela klien di pengadilan, dan membentuk perwakilan di pemerintah lokal maupun pusat. Pekerja sosial membantu serta melindungi klien dari tindakan oknum-oknum yang tidak bertanggungjawab yang memanfaatkan klien (dalam hal ini korban penyalahgunaan narkoba) untuk mendapatkan keuntungan.

5. Mediator

Menurut definisi Gray dan Zide (2013) mediator memiliki arti bahwa pekerja sosial sebagai pihak ketiga yang bersifat netral yang membantu dan memfasilitasi resolusi yang disepakati ketika terjadi perselisihan. Beberapa kegiatan yang dapat dilakukan oleh pekerja sosial dalam menjalankan perannya sebagai mediator diantara lain adalah kontrak perilaku, negosiasi, pendamai pihak ketiga, dan berbagai macam resolusi konflik. Upaya-upaya yang dilakukan dalam mediasi hakekatnya diarahkan untuk mencapai win-win solution. Sebagai mediator strategi yang dilakukan oleh pekerja sosial adalah: (1) Seorang pekerja sosial harus mampu untuk berinteraksi dengan klien; dan (2) seorang pekerja sosial harus mampu menjadi jembatan penghubung antar klien.

6. Konselor

Pada dasarnya pelaksanaan konseling merupakan pemberian nasihat dan dukungan sosial terhadap klien yang dijalankan melalui metode intervensi mikro atau bimbingan sosial perseorangan yang dilaksanakan oleh pekerja sosial. Adapun rehabilitasi sosial yang merupakan kegiatan lanjutan dari upaya penyembuhan korban penyelahgunaan narkoba dalam rangka untuk memulihkan kondisi kesehatan, mental dan sosial seseorang yang telah memiliki ketergantungan terhadap narkoba. Hal tersebut dilakukan sehingga klien dapat kembali melaksanakan fungsi sosialnya di masyarakat. Dengan demikian, konseling termasuk kegiatan yang mendukung proses rehabilitasi sosial dalam upaya untuk meningkatkan keberfungsian klien penyalahgunaan narkoba.

\section{KESI MPULAN DAN SARAN}

Dalam penyelesaian masalah penyalahgunaan narkoba di kalangan remaja dibutuhkan kerja keras, kerja sama dan peran dari berbagai pihak. Salah satu pihak yang memiliki peran yang sangat penting dalam upaya pencegahan penyalahgunaan narkoba adalah keluarga, terutama orangtua. Orangtua dan keluarga adalah lingkungan yang paling dekat yang dapat mempengaruhi perilaku remaja. Oleh karena itu diperlukan peran orangtua dalam penguatan mental dan kepribadian remaja sehingga mereka tidak mudah terbujuk dan terjerumus ke dalam penyalahgunaan narkoba.

Ketidakharmonisan keluarga dan banyaknya konflik yang terjadi di dalam keluarga dapat menjadi salah satu faktor penyebab seseorang terjerumus ke dalam penyalahgunaan narkoba. oleh karena itu orangtua juga memiliki kewajiban untuk menciptakan keluarga bahagia dan sehat sehingga anak-anak mereka tidak rentan terhadap hal-hal negatif. Dengan terciptanya kondisi keluarga yang bahagia dan sehat maka anak akan merasa nyaman berada di lingkungan keluarga dan semakin terhindari dari penyalahgunaan narkoba. 


\begin{tabular}{|c|c|c|c|c|}
\hline $\begin{array}{c}\text { Prosiding Penelitian \& } \\
\begin{array}{c}\text { Pengabdian Kepada } \\
\text { Masyarakat }\end{array}\end{array}$ & $\begin{array}{c}\text { e ISSN : 2581-1126 } \\
\text { p ISSN : 2442-448X }\end{array}$ & Vol 7, No: 1 & Hal: $221-228$ & April 2020 \\
\hline
\end{tabular}

Selain peran-peran yang dilakukan oleh orangtua dalam upaya pencegahan dan penanganan penyalahgunaan narkoba di kalangan remaja, dibutuhkan juga peran-peran tenaga profesional, seperti pekerja sosial. Seorang pekerja sosial harus memiliki kapabilitas dalam mengetahui apa yang harus dilakukan serta mengetahui cara yang akan ditempuh dalam melakukan sesuatu, oleh karena itu peran yang dimiliki oleh pekerja sosial bersifat multiple. Peran-peran yang dapat dilakukan oleh pekerja sosial antara lain sebagai educator, broker, fasilitator, advokator, mediator dan konselor. Pekerja sosial memiliki peran yang sangat penting dalam pencegahan dan penanganan penyalahgunaan narkoba di kalangan remaja, terutama dalam hal pemenuhan hak-hak korban penyalahgunaan narkoba serta mengembalikan fungsi sosial korban penyelahgunaan narkoba di masyarakat.

\section{DAFTAR PUSTAKA}

Amanda, M.P., Humaedi, S., \& Santoso, M.B. (2017). Penyalahgunaan Narkoba Di Kalangan Remaja (Adolescent Substance Abuse). Prosiding Penelitian dan Pengabdian kepada Masayarakat, 4(2).

Eleanora, F. N. (2020). Bahaya Penyalahgunaan Narkoba Serta Usaha Pencegahan Dan Penanggulangannya (Suatu Tinjauan Teoritis). Jurnal hukum, 25(1), 439-452.

Hanifah, A., \& Unayah, N. (2011). Mencegah dan menanggulangi penyalahgunaan napza Melalui peran serta masyarakat. Sosio Informa, 161).

Herdajani, F., \& Rosalinda, I. (2013). Peran Orangtua dalam Mencegah dan Menanggulangi Penggunaan Zat Adiktf dan Psikotropika pada Remaja.

Novia Laksaita, H. (2017). Peran Pekerja Sosial Dalam Rehabilitasi Sosial Bagi Penyalahguna Napza Di Rumah Sehat Orbit Surabaya. J+ PLUS UNESA, 63).

Reza, I. F. (2016). Peran Orang Tua Dalam Penanggulangan Penyalahgunaan Narkoba Pada Generasi Muda. Psikis: Jurnal Psikologi Islami, 2(1).

Rozi, F. (2015). Meningkatkan Peran Orangtua Siswa Dalam Pencegahan Penyalahgunaan Narkoba Melalui Penyuluhan Narkoba Berdasarkan Asesmen Kebutuhan Penyuluhan. Jurnal I/miah Penelitian
Psikologi: Kajian Empiris \& NonEmpiris, 1(1).

Saputro, K. Z. (2018). Memahami ciri dan tugas perkembangan masa remaja. Aplikasia: Jurnal Aplikasi IImu-ilmu Agama, 1ス1), 25-32.

Sudalmi, E. S. (2012). PERAN ORANG TUA DALAM MENDIDIK ANAK SADAR BAHAYA NARKOBA. Eksplorasi, 24(1).

https://bnn.go.id/penggunaan-narkotikakalangan-remaja-meningkat/

https://www.cnnindonesia.com/nasional/2019062 2182557-20-405549/survei-bnn-23-jutapelajar-konsumsi-narkoba 